\title{
Thermodynamic modeling of sulfate-resistant cements with addition of barium compounds
}

\author{
P.M. Carmona-Quiroga, M.T. Blanco-Varela \\ Eduardo Torroja Institute for Construction Science (IETcC-CSIC), Madrid, Spain \\ S. Martínez-Ramírez \\ Institute for the Structure of Matter (IEM-CSIC), Madrid, Spain \\ B. Lothenbach \\ Empa, Laboratory for Concrete \& Construction Chemistry, Dübendorf, Switzerland
}

\begin{abstract}
Sulfate attack by ground waters, soils, etc. is one of the threats to the built heritage in concrete. This study validated through thermodynamic modeling with GEMS geochemical code a new sulfate-resistant formulation based on the addition of $\mathrm{BaCO}_{3}$ and $\mathrm{BaO}$ to ordinary Portland cement (OPC), which could be used to replace weathered concrete. The thermodynamic calculations pointed out that $\mathrm{Ba}$ ions were able to form an insoluble salt, barite $\left(\mathrm{BaSO}_{4}\right)$ with the dissolved sulfate which inhibited the formation of ettringite, the latter occurred when the concentrations of $\mathrm{BaCO}_{3}$ and $\mathrm{BaO}$ were $\geq 6$ and $\geq 4$ wt. $\%$, respectively. The results of a simulated sulfate attack revealed that ettringite precipitated upon ingression of $\geq 46 \mathrm{ml}$ of a $\mathrm{Na}_{2} \mathrm{SO} 4$ solution (44 wt.\%) in OPC blends with $20 \mathrm{wt} . \%$ of $\mathrm{BaCO}_{3}$; whereas with $20 \mathrm{wt} . \%$ of $\mathrm{BaO}$, the sulfate that precipitated besides barite was monosulfoaluminate when sulfate solution was $\geq 40 \mathrm{ml}$ (tested up to $52 \mathrm{ml}$ ).
\end{abstract}

\section{INTRODUCTION}

Much of the twentieth century's heritage (buildings, structures, sculptures and so on) is made of concrete, material susceptible among other weathering phenomenon (Reed et al. 2008) to sulfate attack (Schmidt et al. 2009). The sulfates origin is diverse: internal or external (sulfate-rich water or soil; polluted atmosphere, aggregates and so on). During Portland cement hydration, clinker tricalcium aluminate $\left(3 \mathrm{CaO} \cdot \mathrm{Al}_{2} \mathrm{O}_{3}\right)$, gypsum $\left(\mathrm{CaSO} \cdot 2 \mathrm{H}_{2} \mathrm{O}\right)$ and water react to yield ettringite $\left(3 \mathrm{CaO} \cdot \mathrm{Al}_{2} \mathrm{O}_{3} \cdot 3 \mathrm{CaSO}_{4} \cdot 32 \mathrm{H}_{2} \mathrm{O}\right)$ (eq. 1$)$, one of the main hydrates of cement after C-S-H gel and portlandite $\left(\mathrm{Ca}(\mathrm{OH})_{2}\right)$. The formation of ettringite during the first hours causes no damage in the cementitious materials as they are still in its plastic state (Collepardi 2003). Depletion of the dissolved sulfate leads to the reaction of ettringite with tricalcium aluminate, that yields calcium monosulfoaluminate hydrate $\left(3 \mathrm{CaO} \cdot \mathrm{Al}_{2} \mathrm{O}_{3} \cdot \mathrm{CaSO}_{4} \cdot 12 \mathrm{H}_{2} \mathrm{O}\right)$ (eq. 2).

$$
\begin{aligned}
& 3 \mathrm{CaO} \cdot \mathrm{Al}_{2} \mathrm{O}_{3}+3 \mathrm{CaSO}_{4} \cdot 2 \mathrm{H}_{2} \mathrm{O}+26 \mathrm{H}_{2} \mathrm{O} \rightarrow 3 \mathrm{CaO} \cdot \mathrm{Al}_{2} \mathrm{O}_{3} \cdot 3 \mathrm{CaSO}_{4} \cdot 32 \mathrm{H}_{2} \mathrm{O} \\
& 3 \mathrm{CaO} \cdot \mathrm{Al}_{2} \mathrm{O}_{3} \cdot 3 \mathrm{CaSO}_{4} \cdot 32 \mathrm{H}_{2} \mathrm{O}+2\left(3 \mathrm{CaO} \cdot \mathrm{Al}_{2} \mathrm{O}_{3}\right)+4 \mathrm{H}_{2} \mathrm{O} \rightarrow 3\left(3 \mathrm{CaO} \cdot \mathrm{Al}_{2} \mathrm{O}_{3} \cdot \mathrm{CaSO}_{4} \cdot 12 \mathrm{H}_{2} \mathrm{O}\right)
\end{aligned}
$$

Changes in environmental conditions may destabilize these sulfates and reprecipitation may cause decaying of mortar or concrete. In the presence of external sulfates, the traditional sulfate phases, gypsum, ettringite or thaumasite $\left(\mathrm{CaO} \cdot \mathrm{SiO}_{2} \cdot \mathrm{CaSO}_{4} \cdot \mathrm{CaCO}_{3} \cdot 15 \mathrm{H}_{2} \mathrm{O}\right)$ may crystallize and induce concrete deterioration. Thus, sulfate resistant cements may be needed when weathered concrete should be replaced in restoration works.

Several strategies have been developed to counteract sulfate attack such as sulfate-resistant cements with low $\mathrm{C}_{3} \mathrm{~A}$ content $(<5 \%$, ASTM C150), which avoid the destructive ettringite formation but not the gypsum or thaumasite crystallization. This work proposes the addition of barium compounds $\left(\mathrm{BaCO}_{3}\right.$ (witherite) and $\left.\mathrm{BaO}\right)$ to cement to immobilize sulfate ions by precipi- 
tating barium sulfate, an insoluble salt, further to previous studies of ettringite stability in presence of barium ions (Carmona-Quiroga et al. 2011, Ciliberto et al. 2008).

The main objective of this study was thus to evaluate through thermodynamic modeling, the role of these barium additions on cement hydration and resistance to sulfate attack.

\section{METHODOLOGY}

The influence of barium compounds on cement hydration at $25^{\circ} \mathrm{C}$ was determined using the GEMS geochemical code (Kulik et al. 2012). This thermodynamic modeling software which includes built-in thermodynamic databases (general and cement-specific (Lothenbach et al. 2008), computes equilibrium phase assemblage and speciation of the defined systems by Gibbs free energy minimization (GEM). The bulk chemical composition of the system examined in the present study was the one of an ordinary Portland cement (OPC) (Table 1) blended with up to 20 wt. $\%$ of $\mathrm{BaCO}_{3}$ (witherite) or $\mathrm{BaO}$ (total solid amount of $100 \mathrm{~g}$ ), with a w/c ratio of 0.5 and 1 $\mathrm{g}$ of $\mathrm{CO}_{2}$ free air (assuming $100 \%$ hydration).

The effect of 10 and $20 \mathrm{wt} . \%$ barium compound additions on sulfate attack in cement was also modeled by adding to those systems an increasing amount (up to $52 \mathrm{ml} / 100 \mathrm{~g}$ of cement) of a very high concentration $\mathrm{Na}_{2} \mathrm{SO}_{4}$ solution (44 wt.\%) (In ASTM C1012 the accelerating test is conducted with just $5 \%$ of $\mathrm{Na}_{2} \mathrm{SO} 4$ ).

Table 1. Chemical composition of OPC before blending.

\begin{tabular}{llllllllll}
\hline $\mathrm{OPC}$ & $\mathrm{CaO}$ & $\mathrm{SiO}_{2}$ & $\mathrm{Al}_{2} \mathrm{O}_{3}$ & $\mathrm{Fe}_{2} \mathrm{O}_{3}$ & $\mathrm{MgO}$ & $\mathrm{SO}_{3}$ & $\mathrm{CO}_{2}$ & $\mathrm{Na}_{2} \mathrm{O}$ & $\mathrm{K}_{2} \mathrm{O}$ \\
\hline wt. $\%$ & 65 & 20 & 4.5 & 2.8 & 2 & 2.5 & 2 & 0.4 & 0.8 \\
\hline
\end{tabular}

\section{RESULTS AND DISCUSSION}

\subsection{Influence of $\mathrm{BaCO}_{3}$ and $\mathrm{BaO}$ on cement hydration}

Figure 1 shows the influence of barium compounds on the cement hydrates assemblage. As can be seen, additions of $\mathrm{BaCO}_{3} \geq 6$ wt. $\%$ and $\mathrm{BaO} \geq 4$ wt.\%, destabilized ettringite and promoted the formation of barite $\left(\mathrm{BaSO}_{4}\right)$. If $\mathrm{BaCO}_{3}$ was added, calcium monocarboaluminate hydrate $\left(3 \mathrm{CaO} \cdot \mathrm{Al}_{2} \mathrm{O}_{3} \cdot \mathrm{CaCO}_{3} \cdot 11 \mathrm{H}_{2} \mathrm{O}\right)$ was stabilized, while all sulfate present was bound in barite. The use of $\mathrm{BaO}$ resulted in the conversion of calcium monocarbonate hydrate to hemicarbonate $\left(3 \mathrm{CaO} \cdot \mathrm{Al}_{2} \mathrm{O}_{3} \cdot 0.5 \mathrm{Ca}(\mathrm{OH})_{2} \cdot 0.5 \mathrm{CaCO}_{3} \cdot 11.5 \mathrm{H}_{2} \mathrm{O}\right)$ and hemicarbonate to hydrogarnet $\left(3 \mathrm{CaO} \cdot \mathrm{xAl}_{2} \mathrm{O}_{3} \cdot 1-\mathrm{xFe}_{2} \mathrm{O}_{3} \cdot 6 \mathrm{H}_{2} \mathrm{O}\right.$ ), which favoured the precipitation of more portlandite. Portlandite besides C-S-H gel and hydrotalcite, $\left(\mathrm{Mg}_{6} \mathrm{Al}_{2} \mathrm{CO}_{3}(\mathrm{OH})_{16} \cdot 4\left(\mathrm{H}_{2} \mathrm{O}\right)\right)$ a minor product in the hydration of Portland cement were the only common hydrates for the different concentrations of both barium additions.
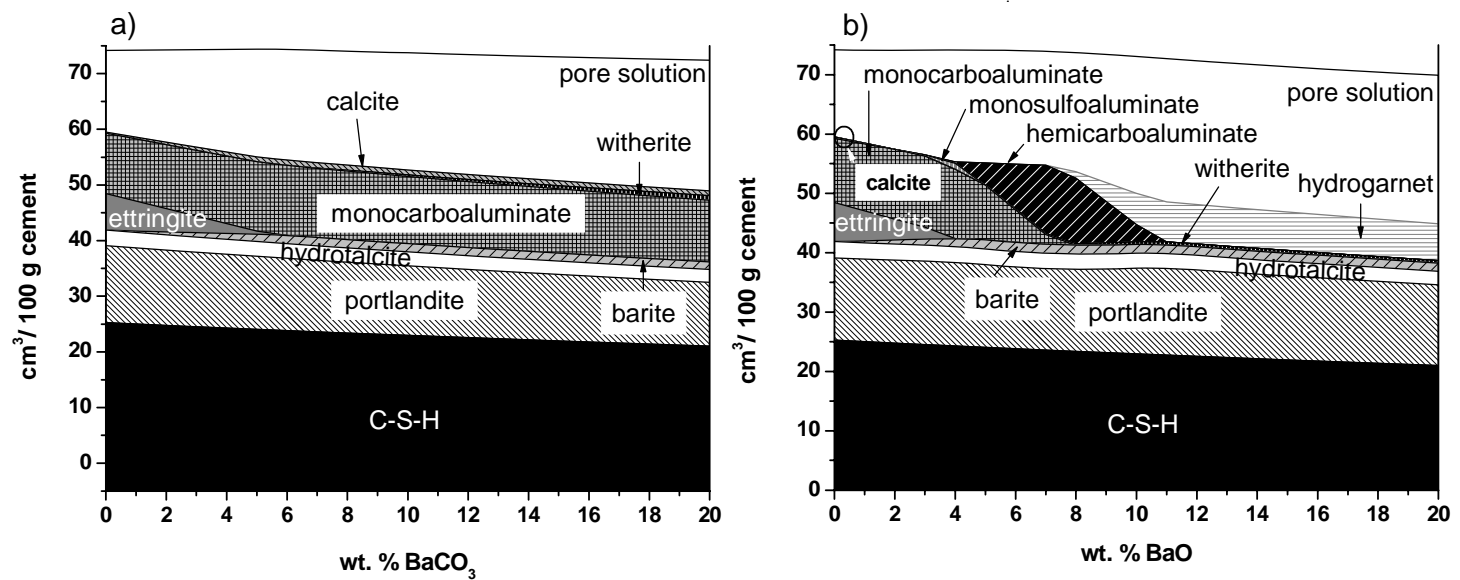

Figure 1. Volume of hydration products of OPC blended with up to 20 wt. $\%$ of $\mathrm{BaCO}_{3}$ (a) and $\mathrm{BaO}$ (b) 


\subsection{Role of $\mathrm{BaCO}_{3}$ and $\mathrm{BaO}$ against sulfate attack}

To simulate external sulfate attack, an increasing amount (up to $52 \mathrm{ml}$ ) of a highly concentrated sodium sulfate solution (44 wt.\%) was calculated to interact with four different model systems: OPC blended with 10 and 20 wt.\% of each $\mathrm{BaCO}_{3}$ and $\mathrm{BaO}$ (Figure 2).
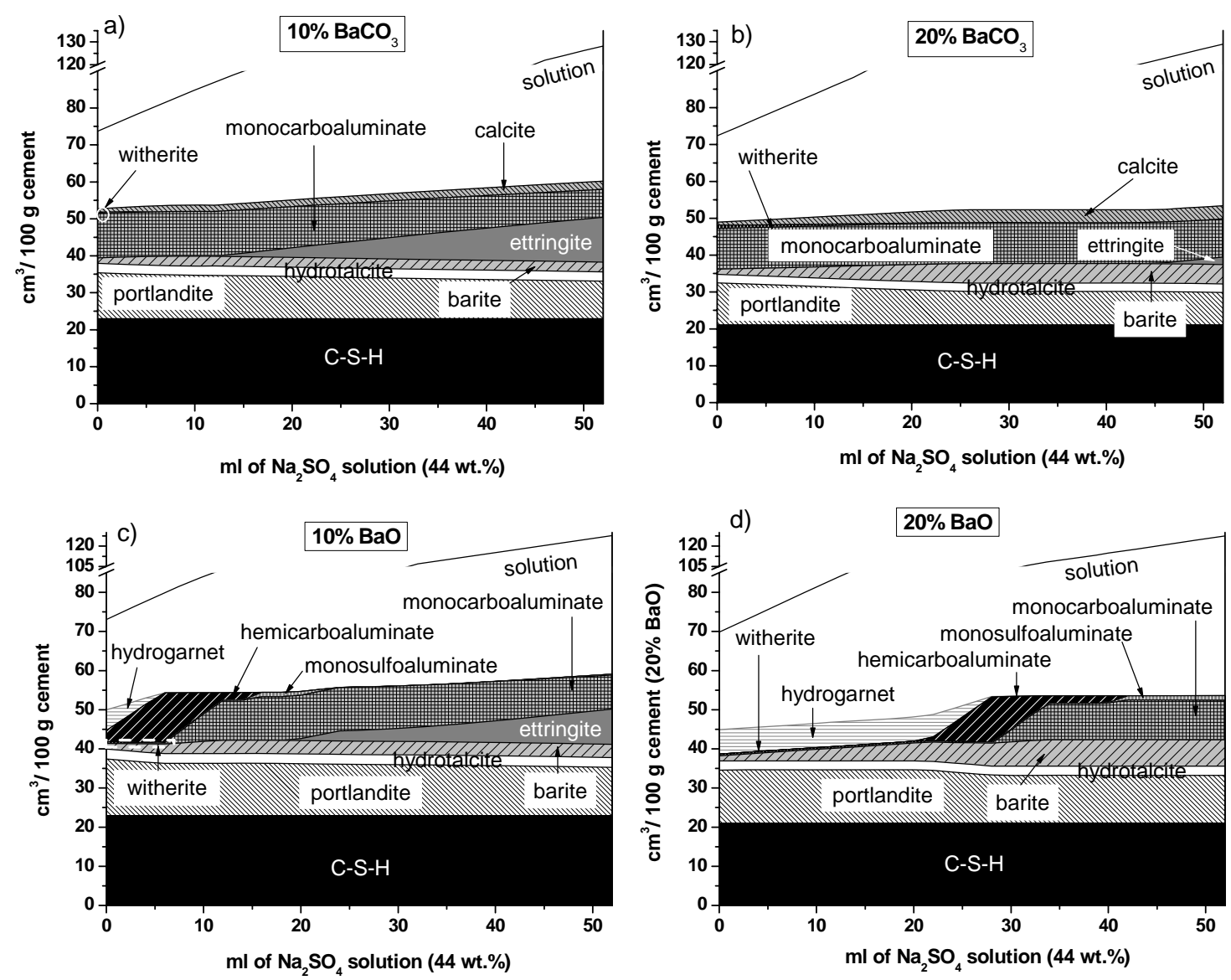

Figure 2. Volume of hydration products of different $\mathrm{OPC}$ blends, (a) with $10 \mathrm{wt} . \%$ of $\mathrm{BaCO}_{3}$; (b) with 20 wt. $\%$ of $\mathrm{BaCO}_{3}$; (c) with 10 wt. $\%$ of $\mathrm{BaO}$ and (c) with 20 wt. $\%$ of $\mathrm{BaO}$, in contact with an increasing amount of a $\mathrm{Na}_{2} \mathrm{SO}_{4}$ solution (44 wt.\%)

The results of thermodynamic modeling allowed predicting the protection limits of the different blends. 10 wt. $\%$ of $\mathrm{BaCO}_{3}$ prevented ettringite precipitation up to $12 \mathrm{ml}$ of $\mathrm{Na}_{2} \mathrm{SO}_{4}$ solution $(0.45 \mathrm{~mol} / \mathrm{kg}$ of $\mathrm{S}$ in dissolution) (Figure $2 \mathrm{a})$, whereas $20 \mathrm{wt} \%$ of $\mathrm{BaCO}_{3}$ avoided ettringite formation up to $44 \mathrm{ml}$ of the aggressive solution $(0.91 \mathrm{~mol} / \mathrm{kg}$ of $\mathrm{S}$ in dissolution) (Figure $2 \mathrm{~b}$ ). Nonetheless, taking into account the aggressiveness of the solution both blends could be considered as sulfate-resistants.

Unlike $\mathrm{BaCO}_{3}, \mathrm{BaO}$ did not prevent the formation of a small amount (maximum content around $1 \mathrm{~cm}^{3}$ ) of monosulfolauminate prior to ettringite precipitation but guaranteed even a better protection against sulfate attack by delaying the formation of the ettringite. In fact, no ettringite was able to precipitate with $20 \mathrm{wt} . \%$ of $\mathrm{BaO}$ for the simulated attack (Figure $2 \mathrm{~d}$ ) and with 10 wt. $\%$ of $\mathrm{BaO}$ started to precipitate with a higher amount of the aggressive solution, 20 $\mathrm{ml}$, (Figure 2c) in smaller quantities. 


\section{CONCLUSIONS}

According to thermodynamic calculations with GEMS geochemical code, $\mathrm{BaCO}_{3}$ and $\mathrm{BaO}$ additions $\geq 6 \mathrm{wt} . \%$ and $\geq 4 \mathrm{wt} . \%$, respectively, stabilize cement sulfates by precipitating barite $\left(\mathrm{BaSO}_{4}\right)$, a very insoluble and thus stable sulfate, instead of ettringite. This explains the favourable results of OPC blends with 10 and $20 \mathrm{wt} . \%$ of these barium compounds, especially with $20 \%$ of $\mathrm{BaO}$, against sulfate attack after modeling the ingression of highly concentrated (44 wt.\%) $\mathrm{Na}_{2} \mathrm{SO}_{4}$ solution (up to $52 \mathrm{ml}$ ) in those systems.

These results endorse the addition of $\mathrm{BaCO}_{3}$ and $\mathrm{BaO}$ to OPC to produce new sulfate resistant cements which can be used to replace weathered concrete of our recent heritage, although as a rule, predictions should be always experimentally confirmed.

\section{ACKNOWLEDGEMENTS}

Funding from the Spanish Ministry of Education and Science (Project CONSOLIDER CSD2007-00058) and the Regional Government of Madrid (Geomaterials Programme) is gratefully acknowledged.

\section{REFERENCES}

ASTM Standard C150 / C150M - 12. 2012. Specification for Portland cement. Philadelphia: ASTM International.

ASTM Standard C1012 / C1012M - 12. 2012. Test method for lenght change of hydraulic-cement mortar exposed to a sulfate solution. Philadelphia: ASTM International.

Carmona-Quiroga, P.M., Martínez-Ramírez, S., Blanco-Varela, M.T. 2011. Thermodynamic stability of hydrated Portland cement phases in the presence of barium carbonates. In A. Palomo, A. Zaragoza, J.C. López Agüí (eds), XIII International Congress on the Chemistry of Cement; Proc. Intern. Symp., Madrid, 3-8 July 2011. Madrid. Eduardo Torroja Institute for Construction Science.

Ciliberto, E., Ioppolo, S., Manuella, F. 2008. Ettringite and thaumasite: A chemical route for their removal from cementious artefacts. Journal of Cultural Heritage 9(1): 30-37.

Collepardi, M. 2003.A state-of-the-art review on delayed ettringite attack on concrete. Cement and Concrete Composites 25 (4-5): 401-407.

Kulik, D., Wagner, T., Dmytrieva, S.V., Kosakowski, G., Chudnenko, K.V., Berner, U. 2012. GEMselektor geochemical modelling package: numerical kernel GEMS3K for coupled simulation codes. Computational Geochemistry in press, doi: http://dx.doi.org/10.1007/s10596-012-9310-6.

Lothenbach, B., Matschei, T., Möschner, G., Glasser, F.P. 2008. Thermodynamic modelling of the effect of temperature on the hydration and porosity of Portland cement. Cement and Concrete Research 38(1): 1-18.

Reed, P., Schoonees, K., Salmond, J. 2008. Historic concrete structures in New Zealand. Overview, maintenance and management. Wellington: Department of Conservation.

Schmidt, T., Lothenbach, B., Romer, M., Neuenschwander; J., Scrivener, K. 2009. Physical and microstructural aspects of sulfate attack on ordinary and limestone blended Portland cements. Cement and Concrete Research 39(12): 1111-1121. 